Praca poglądowa/Review

\title{
Wskazania do transplantacji komórek krwiotwórczych u dzieci i młodzieży - rekomendacje Polskiej Pediatrycznej Grupy ds. Transplantacji Komórek Krwiotwórczych - 2014
}

\section{Indications for hematopoietic stem cell transplantation in children and adolescents - recommendations of the Polish Pediatric Group for Hematopoietic Stem Cell Transplantation in the year 2014}

\author{
Jacek Wachowiak $^{1, *}$, Walentyna Balwierz ${ }^{2}$, Alicja Chybicka ${ }^{3}$, \\ Katarzyna Drabko ${ }^{4}$, Ewa Gorczyńska ${ }^{3}$, Jolanta Goździk ${ }^{5}$, Krzysztof Kałwak ${ }^{3}$, \\ Bernarda Kazanowska ${ }^{3}$, Jerzy R. Kowalczyk ${ }^{4}$, Michał Matysiak ${ }^{6}$, \\ Jan Styczyński ${ }^{7}$, Marek Ussowicz ${ }^{3}$, Grażyna Wróbel ${ }^{3}$, Mariusz Wysocki ${ }^{7}$ \\ ${ }^{1}$ Klinika Onkologii, Hematologii i Transplantologii Pediatrycznej UM w Poznaniu, Kierownik: prof. dr hab. Jacek \\ Wachowiak, Poznań, Polska \\ ${ }^{2}$ Klinika Onkologii i Hematologii Dziecięcej PAIP CM UJ, Kierownik: prof. dr hab. Walentyna Balwierz, Kraków, Polska \\ ${ }^{3}$ Klinika Transplantacji Szpiku, Onkologii i Hematologii Dziecięcej UM we Wrocławiu, Kierownik: prof. dr hab. Alicja \\ Chybicka, Wrocław, Polska \\ ${ }^{4}$ Klinika Hematologii, Onkologii i Transplantologii Dziecięcej UM w Lublinie, Kierownik: prof. dr hab. Jerzy R. \\ Kowalczyk, Lublin, Polska \\ ${ }^{5}$ Oddział Przeszczepiania Komórek Krwiotwórczych Ośrodka Transplantacji PAIP CM UJ, Kierownik: dr hab. Jolanta \\ Goździk, Kraków, Polska \\ ${ }^{6}$ Klinika Pediatrii, Hematologii i Onkologii UM w Warszawie, Kierownik: prof. dr hab. Michał Matysiak, Warszawa, Polska \\ ${ }^{7}$ Klinika Pediatrii, Hematologii i Onkologii CM UMK w Bydgoszczy, Kierownik: prof. dr hab. Mariusz Wysocki, \\ Bydgoszcz, Polska
}

IN FORMACJE O ARTYKULE

Historia artykułu:

Otrzymano: 23.07.2014

Zaakceptowano: 01.09.2014

Dostępne online: 16.09 .2014

Słowa kluczowe:

- transplantacja komórek krwiotwórczych

\begin{abstract}
A B S T R A C T
This article presents the current recommendations from the Polish Pediatric Group for Hematopoietic Stem Cell Transplantation concerning the indications for hematopoietic stem cell transplantation (HSCT) in children and adolescents suffering from hematological malignancies, solid tumours, and congenital or acquired non-malignant disorders. Indications for HSCT are established in context of the recent results of conventional treatment, i.e. obtained with non-HSCT strategies; it means transplantation is justifiable exclusively, when it significantly increases individual patient's chances to be cured, despite of the risk of HSCT-related mortality. Hence, due to the advances of non-transplant
\end{abstract}

\footnotetext{
* Adres do korespondencji: Klinika Onkologii, Hematologii i Transplantologii Pediatrycznej Uniwersytet Medyczny im. Karola Marcinkowskiego, ul. Szpitalna 27/33, 60-572 Poznań, Polska. Tel.: +48 61849 14 47; fax: +48 618474356.

Adres email: jacek.wachowiak@plusnet.pl (J. Wachowiak).

http://dx.doi.org/10.1016/j.achaem.2014.09.001

0001-5814/@ 2014 Polskie Towarzystwo Hematologów i Transfuzjologów, Instytut Hematologii i Transfuzjologii. Published by Elsevier
} Urban \& Partner Sp. z o.o. All rights reserved. 
- wskazania

- dzieci

- młodzież

Keywords:

- Hematopoietic stem cell transplantation

- Indications

- Children

- Adolescents treatment strategies as well as progress in the field of HSCT the indications for HSCT require to be regularly up-dated. The recommendations presented in this article are based on the current guidelines from the European Group for Blood and Bone Marrow Transplantation (EBMT), including those from the EBMT Pediatric Diseases Working Party and the EBMT Inborn Errors Working Party, and from the international treatment protocols currently applied in the centers of the Polish Pediatric Leukemia/Lymphoma Study Group and Polish Pediatric Solid Tumours Study Group. The recommendations are addressed not only to the Polish pediatric transplant centers, but first of all to the Polish pediatric centers involved in diagnostics and treatment of the malignancies and nonmalignant disorders in children and adolescents with non-transplant strategies, because it is their responsibility to identify as soon as possible indications for HSCT and refer patient at the appropriate time to pediatric transplant center.

(C) 2014 Polskie Towarzystwo Hematologów i Transfuzjologów, Instytut Hematologii i Transfuzjologii. Published by Elsevier Urban \& Partner Sp. z o.o. All rights reserved.

\section{Wstęp}

Wskazania do transplantacji komórek krwiotwórczych (hematopoietic stem cell transplantation; HSCT) w chorobach nowotworowych oraz we wrodzonych i nabytych chorobach nierozrostowych $u$ dzieci i młodzieży ustalane są w kontekście wyników leczenia konwencjonalnego, a zabieg jest uzasadniony tylko wtedy, gdy znamiennie zwiększa szansę chorego na wyleczenie. Stąd, ze względu na postępy leczenia konwencjonalnego oraz postępy HSCT, wskazania do transplantacji wymagają systematycznej aktualizacji.

Przedstawione szczegółowe wskazania do allogenicznej i autologicznej HSCT u dzieci i młodzieży zostały ustalone podczas posiedzeń Polskiej Pediatrycznej Grupy ds. Transplantacji Komórek Krwiotwórczych (PPGdsTKK) Polskiego Towarzystwa Onkologii i Hematologii Dziecięcej (PTOiHD), które odbyły się w dniu 6 czerwca 2013 r. oraz 28 maja 2014 r. i uwzględniają aktualne zalecenia European Group for Blood and Bone Marrow Transplantation (EBMT) zawarte w 6. wydaniu EBMT Handbook z 2012 r. [1], w tym zalecenia EBMT Pediatric Diseases Working Party oraz EBMT Inborn Errors Working Party, a także zalecenia zawarte w protokołach terapeutycznych aktualnie obowiązujących w ośrodkach Polskiej Pediatrycznej Grupy ds. Leczenia Białaczek i Chłoniaków (PPGdsLBiCh) oraz Polskiej Pediatrycznej Grupy ds. Guzów Litych (PPGdsGL) PTOiHD.

\section{Wskazania do HSCT w chorobach rozrostowych u dzieci}

W zależności od wyników leczenia chorób rozrostowych układu krwiotwórczego przy użyciu chemioterapii konwencjonalnej, HSCT może pełnić rolę:

- metody leczenia z wyboru w chorobach, w których całkowicie zawodzą konwencjonalne metody terapii (wyłącznie allogeniczna HSCT, allo-HSCT);

- konsolidacji pierwszej pełnej remisji (first complete remission; CR1) w przypadku choroby rozrostowej z wykładnikami wysokiego ryzyka nawrotu (allo-HSCT lub autologiczna HSCT, auto-HSCT);
- konsolidacji $C R \geq 2$, gdy konwencjonalna terapia nie zapobiegła wystąpieniu pierwszego lub kolejnego nawrotu choroby i niedostatecznie zabezpiecza przed następnym (allo-HSCT lub auto-HSCT);

\section{Choroby rozrostowe układu krwiotwórczego}

\section{Ostra białaczka limfoblastyczna (acute lymphoblastic leukemia; ALL)}

Allo-HSCT wykonuje się wyłącznie $u$ tych dzieci $z$ ALL, u których chemioterapia nadal zbyt często zawodzi, tj. $\mathrm{u}$ dzieci w CR1 z grupy wysokiego ryzyka (high risk; HR), u których spostrzega się wykładniki najwyższego ryzyka, oraz u dzieci, u których pomimo zastosowanej chemioterapii doszło do wznowy białaczki. Czynnikiem, od którego w największym stopniu zależy trwałość remisji ALL po allo-HSCT, jest poziom choroby resztkowej (minimal residual disease; MRD) spostrzegany przed zabiegiem. Auto-HSCT nie jest obecnie rekomendowana $u$ dzieci z ALL.

HR-ALL W CR1. W Polsce od 2012 r. dzieci z ALL są kwalifikowane do grup rokowniczych i leczone zgodnie z wytycznymi programu terapeutycznego ALL-IC BFM 2009, a aktualne wskazania do allo-HSCT u dzieci z HR-ALL $\mathrm{w}$ pierwszej pełnej remisji (first complete remission; CR1) ustalono $\mathrm{z}$ uwzględnieniem rekomendacji zawartych programach ALL IC-BFM 2009 [2] i AIEOP-BFM ALL 2009 (w wersji nieuwzględniającej wyników oceny poziomu MRD oznaczanego w oparciu o detekcję rearanżacji genów Ig/TCR ilościową metodą PCR w czasie rzeczywistym [RQ-PCR]) [3] oraz w programie EsPhALL v. 01/12/2009 [4] (Tab. I).

W zależności od konstelacji spostrzeganych wykładników wysokiego ryzyka wznowy dawcą allogenicznych komórek krwiotwórczych dla dziecka z HR-ALL w CR1 może być nie tylko rodzeństwo zgodne w zakresie antygenów układu HLA (matched sibling donor; MSD), ale także dawca rodzinny lub dawca niespokrewniony zgodny w 10/10 alelli w loci A, B, Cw, DRB1 i DQB1 lub z jedną niezgodnością alleliczną w jednym z ww. loci za wyjątkiem niezgodności w locus DRB1 (matched donor; MD) oraz dawca rodzinny lub dawca niespokrewniony częściowo niezgodny w HLA (mismatched donor; MMD).

Należy jednak podkreślić, że obecnie u dzieci z ALL najbardziej obiektywnym, a tym samym najważniejszym 
Tabela I - Wskazania do allogenicznej transplantacji komórek krwiotwórczych i typ dawcy u dzieci i mlodzieży w I remisji ostrej bialaczki limfoblastycznej z grupy wysokiego ryzyka wedlug programu ALL-IC BFM 2009, AIEOP-BFM ALL 2009 oraz EsPhALL v. 01/12/2009

Table I - Indications for allogeneic hematopoietic cell transplantation and donor type in children and adolescents in the remission of acute lymphoblastic leukemia at high risk according to the program ALL-IC BFM 2009, AIEOP-BFM ALL 2009 and the EsPhALL v. 01/12/2009

\begin{tabular}{|c|c|c|c|c|}
\hline \multicolumn{2}{|l|}{ Wskazania } & MSD & MD & MMD \\
\hline \multicolumn{2}{|l|}{$\begin{array}{l}\text { brak remisji w dniu 33. leczenia } \\
\text { indukującego }\end{array}$} & + & + & + \\
\hline \multirow{2}{*}{$\begin{array}{l}\text { niezależnie od odpowiedzi na } \\
\text { wstępną kortykosteroidoterapię }\end{array}$} & $\mathrm{t}(4 ; 11)$ lub MLL-AF4 & + & + & - \\
\hline & hipodiploidia $<44$ chromosomów & + & + & - \\
\hline \multirow[t]{3}{*}{ PPR } & $\mathrm{t}(9 ; 22)$ lub BCR-ABL & + & + & + \\
\hline & T-ALL & + & + & - \\
\hline & pro B-ALL + WBC > $100000 / \mu l$ & + & - & - \\
\hline PGR & $\mathrm{t}(9 ; 22)$ lub $B C R-A B L$ & + & - & - \\
\hline HR & szpik M3 w 15. dniu indukcji & + & - & - \\
\hline \multicolumn{5}{|c|}{$\begin{array}{l}\text { MSD - rodzeństwo zgodne w HLA; MD - dawca rodzinny lub dawca niespokrewniony zgodny w 10/10 alelli w loci A, B, Cw, DRB1 i DQB1 lub } \\
\text { z niezgodnością alleliczną w jednym z ww. loci za wyjątkiem niezgodności w locus DRB1; MMD - dawca rodzinny lub dawca niespokrewniony } \\
\text { częściowo niezgodny w HLA; PGR - dobra odpowiedź na prednizon; PPR - zła odpowiedź na prednizon; WBC - liczba krwinek białych w krwi } \\
\text { obwodowej w chwili rozpoznania. }\end{array}$} \\
\hline
\end{tabular}

czynnikiem rokowniczym jest poziom MRD oznaczany na podstawie detekcji rearanżacji genów Ig/TCR ilościową metodą PCR w czasie rzeczywistym (RQ-PCR) w 33. dniu i 12. tygodniu terapii, tj. na zakończenie leczenia indukującego remisję i bezpośrednio przed rozpoczęciem leczenia konsolidującego. Stąd, jeśli dostępne są wyniki oznaczeń MRD metodą RQ-PCR, to nawet $\mathrm{w}$ przypadku występowania innych ważnych czynników niekorzystnego rokowania, w tym braku pełnej remisji w 33. dobie leczenia indukującego, translokacji (4; 11), hipodiploidii <44 chromosomów i/lub złej odpowiedzi na prednizon w 8. dobie leczenia wraz z T-komórkowym immunofenotypem limfoblastów, wskazania do transplantacji i dopuszczalny typ dawcy macierzystych komórek krwiotwórczych (hematopoietic stem cell; HSC)

Tabela II - Wskazania do allogenicznej transplantacji komórek krwiotwórczych i rekomendowany typ dawcy wedlug programu AIEOP-BFM ALL 2009 u dzieci i mlodzieży w I remisji ostrej bialaczki limfoblastycznej w zależności od poziomu choroby resztkowej oznaczanego metodą RQ-PCR

Table II - Indications for allogeneic hematopoietic cell transplantation and donor type recommended by the program AIEOP-BFM ALL 2009 for children and adolescents in the remission of acute lymphoblastic leukemia according to the level of residual disease denoted by RQ-PCR

Grupy ryzyka w zależności od poziomu MRD ocenianego metodą RQ-PCR

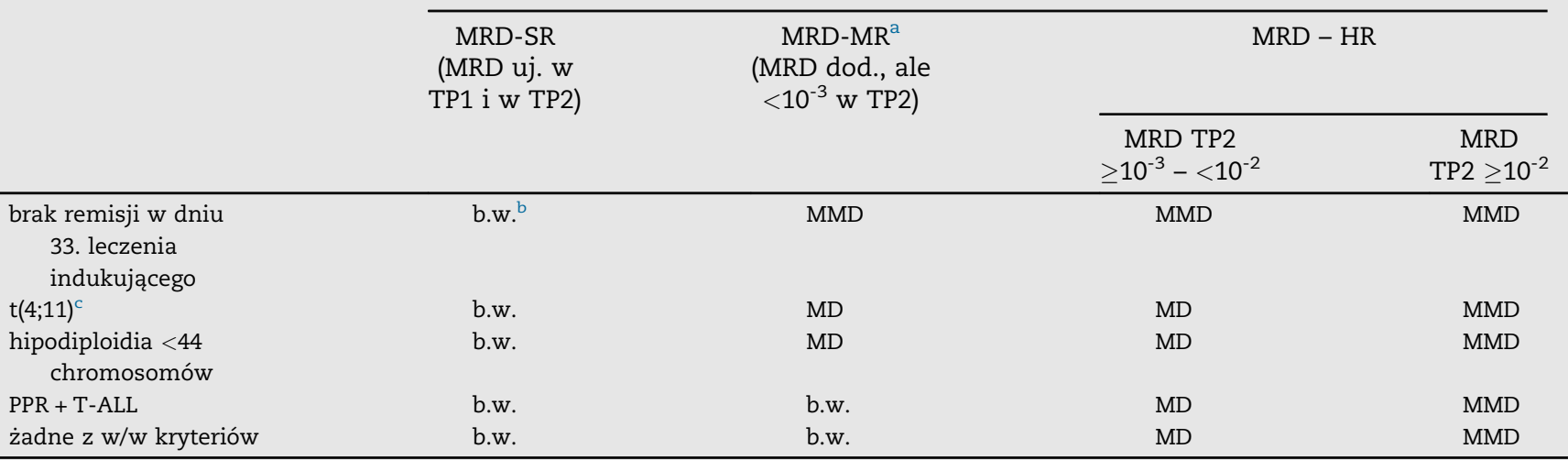

MRD - minimalna choroba resztkowa; SR - standardowe ryzyko wznowy; MR - pośrednie ryzyko wznowy; HR - wysokie ryzyko wznowy; b.w. brak wskazań do allo-HSCT; MSD - rodzeństwo zgodne w HLA; MD - dawca rodzinny lub dawca niespokrewniony zgodny w 10/10 alelli w loci A, B, Cw, DRB1 i DQB1 lub z niezgodnością alleliczną w jednym z w/w loci za wyjątkiem niezgodności w locus DRB1; MMD - dawca rodzinny lub dawca niespokrewniony częściowo niezgodny w HLA; PPR - zła odpowiedź na prednizon; TP1 - pierwszy punkt czasowy, tj. 33. doba leczenia indukującego remisję; TP2 - drugi punkt czasowy, tj. 12. tydzień leczenia;

${ }^{a} \mathrm{z}$ uwzględnieniem tzw. slow early responders (SER), tj. MRD w TP1 $\geq 10^{-3}$ i MRD w TP2 $10^{-4 /-5}$

${ }^{\mathrm{b}}$ brak remisji wyłącznie $\mathrm{w}$ odniesieniu do pozaszpikowej lokalizacji choroby, wskazania do allo-HSCT należy ustalać indywidualnie w porozumieniu z koordynatorem krajowym.

${ }^{c}$ niezależnie od odpowiedzi na prednizon w 8. dobie leczenia. 
Tabela III - Kwalifikacja do grup rokowniczych dzieci i młodzieży ze wznową ostrej bialaczki limfoblastycznej leczoną wedlug programu IntReALL 2010

Table III - Qualification for prognostic groups of children and adolescents with recurrent acute lymphoblastic leukemia treated according to the program IntReALL 2010

\begin{tabular}{|c|c|c|c|c|c|c|}
\hline CZAS & \multicolumn{3}{|c|}{ OD ROZPOZNANIA } & \multicolumn{3}{|c|}{ OD ZAKOŃCZENIA LECZENIA } \\
\hline PÓŹNA & & \multicolumn{3}{|c|}{$>6$ miesięcy } \\
\hline WCZESNA & \multicolumn{3}{|c|}{ >18 miesięcy } & \multicolumn{3}{|c|}{$<6$ miesięcy } \\
\hline BARDZO WCZESNA & \multicolumn{3}{|c|}{$<18$ miesięcy } & \multicolumn{3}{|c|}{$<6$ miesięcy } \\
\hline & \multicolumn{3}{|c|}{ IMMUNOFENOTYP: nie-T } & \multicolumn{3}{|c|}{ IMMUNOFENOTYP: (pre-)T } \\
\hline LOKALIZACJA & \multirow{2}{*}{$\begin{array}{c}\text { Pozaszpikowa } \\
\text { izolowana }\end{array}$} & \multicolumn{2}{|c|}{ Szpikowa } & \multirow{2}{*}{$\begin{array}{c}\text { Pozaszpikowa } \\
\text { izolowana }\end{array}$} & \multicolumn{2}{|c|}{ Szpikowa } \\
\hline CZAS & & mieszana & izolowana & & mieszana & izolowana \\
\hline BARDZO WCZESNA & $\mathrm{HR}$ & HR & HR & $\mathrm{HR}$ & HR & HR \\
\hline WCZESNA & SR & SR & HR & SR & $\mathrm{HR}$ & HR \\
\hline PÓŹNA & SR & SR & SR & SR & HR & HR \\
\hline
\end{tabular}

SR - standardowe ryzyko wznowy; HR - wysokie ryzyko wznowy.

ustalane są w kontekście poziomu MRD (Tab. II). Natomiast ze względu na brak pełnej korelacji pomiędzy wynikami oznaczeń MRD metodą RQ-PCR i metodą 8-kolorowej cytofluorymetrii przepływowej, te ostatnie jak dotąd nie znajdują zastosowania w kwalifikacji do allo-HSCT, a jedynie w kwalifikacji do grup rokowniczych.

Niemowlęca ALL w CR1. Niemowlęta z ALL leczone są według programu INTERFANT-06 (wersja nr 14 z 23.05.2012 r.) [5]. Zgodnie $\mathrm{z}$ tym programem, allo-HSCT w CR1 należy przeprowadzić u wszystkich niemowląt - niezależnie od poziomu MRD - z grupy wysokiego ryzyka (HR) (wiek przy rozpoznaniu $<6$ miesięcy $[<183$ dni], rearanżacja MLL, wstępna leukocytoza blastyczna $>300 \times 10^{9} / 1$ i/lub niekorzystna odpowiedź na wstępną kortykosteroidoterapię, jeśli spełnione są wymienione trzy kryteria), a także u pacjentów z grupy ryzyka pośredniego (MR) z poziomem $\mathrm{MRD} \geq 10^{-4}$ przed rozpoczęciem bloku OCTADA(D); punkt czasowy TP5). Poziom MRD powinien być oznaczany metodą RQ-PCR w jednym z referencyjnych laboratoriów współpracujących w ramach ESG-MRD-ALL Consortium. U dzieci z grupy HR transplantację należy przeprowadzić po bloku MARMA lub po bloku OCTADA(D), a u pacjentów $\mathrm{z}$ grupy MR po bloku
OCTADA(D). Zabieg powinien być przeprowadzony w ciągu 4 tygodni od zakończenia jednego $\mathrm{z}$ wymienionych bloków leczenia, jednak nie później jak 8 miesięcy od rozpoznania białaczki. Dawcą komórek krwiotwórczych może być MSD lub MD. W tym miejscu należy wspomnieć, że ze względu na wysoki odsetek niepowodzeń spowodowanych toksycznością narządową kondycjonowania złożonego z busulfanu, cyklofosfamidu i melfalanu, to ostanie decyzją koordynatorów programu terapeutycznego INTERFANT-06 zostało zastąpione w maju 2012 r. kondycjonowaniem opartym na treosulfanie, fludarabinie i tiotepie.

$\underline{\text { ALL } w} \geq \underline{\text { CR2 }}$. Obecnie dzieci ze wznową ALL leczone są według programu IntReALL 2010 [6, 7], który w zależności od czasu wystąpienia wznowy, immunofenotypu limfoblastów oraz lokalizacji wznowy wyróżnia dwie grupy ryzyka, tj. grupę ryzyka standardowego (SR) i grupę ryzyka wysokiego (HR) (Tab. III).

Wskazania do allo-HSCT u dzieci z ALL w CR2 (rozszerzone w porównaniu z poprzednio stosowanym protokołem ALL-Rez BFM 2002) i rekomendowany typ dawcy komórek krwiotwórczych zostały ustalone $\mathrm{z}$ uwzględnieniem grupy ryzyka i odpowiedzi na terapię ocenianej na poziomie MRD

Tabela IV - Wskazania do allogenicznej transplantacji komórek krwiotwórczych u dzieci i mlodzieży z ALL w $\geq$ CR2 wedlug programu IntReALL 2010

Table IV - Indications for allogeneic hematopoietic cell transplantation in children and adolescents with ALL in $\geq$ CR2 according to the program IntReALL 2010

\begin{tabular}{|c|c|c|c|c|c|c|c|c|c|}
\hline \multirow[t]{3}{*}{ HSCT } & \multicolumn{8}{|c|}{ SR } & \multirow[t]{3}{*}{ HR } \\
\hline & \multicolumn{3}{|c|}{$\begin{array}{c}\text { Późna izolowana lub mieszana } \\
\text { wznowa szpikowa }\end{array}$} & \multicolumn{3}{|c|}{$\begin{array}{l}\text { Wczesna mieszana wznowa } \\
\text { szpikowa }\end{array}$} & \multicolumn{2}{|c|}{$\begin{array}{l}\text { Izolowana wznowa } \\
\text { pozaszpikowa }\end{array}$} & \\
\hline & MRD GR & MRD PR & MRD ND & MRD GR & MRD PR & MRD ND & Późna & Wczesna & \\
\hline MD & Nie & Tak & Tak & Tak & Tak & Tak & Nie & Tak & Tak \\
\hline MMD & Nie & Tak & Nie & Nie & Tak & Tak & Nie & Nie & Tak \\
\hline
\end{tabular}

MSD - rodzeństwo zgodne w HLA; MD - dawca rodzinny lub dawca niespokrewniony zgodny w 10/10 alelli w loci A, B, Cw, DRB1 i DQB1 lub z niezgodnością alleliczną w jednym z ww. loci za wyjątkiem niezgodności w locus DRB1; MMD - dawca rodzinny lub dawca niespokrewniony częściowo niezgodny w HLA.

MRD GR - dobra odpowiedź na leczenie indukujące remisję na poziomie MRD (w ramieniu A - MRD $\leq 10^{-3}$; w ramieniu $\mathrm{B}-\leq 10^{-4}$ ); MRD PR - zła odpowiedź na leczenie indukujące remisję na poziomie MRD (w ramieniu A - MRD $\geq 10^{-3}$; w ramieniu B - $\geq 10^{-4}$ ); MRD ND - brak wyniku MRD. 
(jeśli wykonywane są oznaczenia MRD) (Tab. IV). Zaleca się monitorowanie MRD metodą RQ-PCR, jednak jeśli nie jest możliwe zastosowanie metody RQ-PCR, to dopuszcza się oznaczenie poziomu MRD metodą wieloparametrycznej cytometrii przepływowej.

W grupie SR stosowana jest terapia wg ramienia SR-A (w oparciu o stosowany wcześniej protokół ALL-Rez BFM 2002) lub SR-B (w oparciu o protokół ALLR3). W grupie SR u pacjentów z późną mieszaną wznową i niskim poziomem MRD (w 28. dniu $<0,1 \%$ dla ramienia SRA lub $w 35$. dniu $<0,01 \%$ dla ramienia SRB) oraz u pacjentów $z$ izolowaną późną wznową pozaszpikową stosuje się leczenie podtrzymujące remisję, natomiast u wszystkich pozostałych dzieci należy w okresie 14.-17. tygodnia leczenia przeprowadzić allo-HSCT.

Jeżeli u pacjenta $\mathrm{z}$ grupy SR $\mathrm{z}$ późną izolowaną lub kombinowaną wznową szpikową nie ma możliwości oceny poziomu MRD po leczeniu indukującym remisję, to dawcą komórek krwiotwórczych może być - w odpowiedniej kolejności - wyłącznie MSD lub tzw. dawca zgodny (matched donor; $\mathrm{MD}$ ), tj. dawca rodzinny lub dawca niespokrewniony zgodny w 10/10 alelli w loci A, B, Cw, DRB1 i DQB1 lub $\mathrm{z}$ niezgodnością alleliczną w jednym $\mathrm{z}$ ww. loci za wyjątkiem niezgodności w locus DRB1.

W grupie HR wszyscy pacjenci, którzy osiągną remisję hematologiczną, najlepiej z poziomem MRD $<0,1 \%$, powinni być poddani allo-HSCT w 14 . tygodniu leczenia po 4 cyklach chemioterapii (cykl indukcji remisji plus 3 cykle konsolidujące), a dawcą HSC może być, w odpowiedniej kolejności, nie tylko MSD lub MD, ale także MMD. Natomiast jeśli w 11. tygodniu leczenia poziom MRD wynosi $\geq 0,1 \%$, to należy podjąć leczenie w ramach badań klinicznych II fazy lub indywidualną terapię zarekomendowaną przez koordynatora krajowego ds. leczenia wznowy ALL u dzieci.

Ostra białaczka szpikowa (acute myeloblastic leukemia; AML) HSCT wskazana jest u tych dzieci z AML, u których chemioterapia pierwszej linii zawiodła (pierwotnie oporna AML, wznowa AML), a także u tych, u których nadal zbyt często zawodzi, tj. u dzieci z AML w CR1 z grupy wysokiego ryzyka wznowy (HR).

HR-AML w CR1. Od 2005 r. dzieci z pierwszym objawem AML leczone są w Polsce według programu AML-BFM 2004 INTERIM [8], natomiast kwalifikacja tych dzieci do allo-HSCT dokonywana jest na podstawie odpowiedzi na leczenie ocenianej $\mathrm{w}$ 42. dobie terapii oraz $\mathrm{w}$ miarę możliwości w oparciu o wyniki badań cytogenetycznych lub molekularnych zgodnie z rekomendacjami programu Registry AML-BFM 2012 [9] (Tab. V). Jeśli spełnione zostaną kryteria kwalifikacyjne określone przez program Registry AML-BFM 2012, to dawcą komórek krwiotwórczych może być MSD lub MD.

Jeśli w chwili rozpoznania AML nie przeprowadzono badań cytogenetycznych i molekularnych w zakresie umożliwiającym uwzględnienie rekomendacji programu Registry AML-BFM 2012, to dziecko z AML nadal kwalifikowane jest do grupy rokowniczej oraz do allo-HSCT w CR1 zgodnie ze wskazaniami określonymi w programie AML-BFM 2004 INTERIM (Tab. VI), a dawcą komórek krwiotwórczych może być wyłącznie MSD.

Badania antygenów układu HLA u dziecka z AML oraz jego rodziców i rodzeństwa należy wykonać już w chwili rozpoznania białaczki, a w przypadku braku zgodnego w HLA dawcy wśród rodzeństwa i stwierdzenia wskazań do transplantacji od zgodnego dawcy niespokrewnionego (MD) należy niezwłocznie podjąć poszukiwanie takiego dawcy. U dzieci z HR-AML w CR1 i wskazaniami do allo-HSCT zabieg przeprowadza się 4-6 tygodni po zakończeniu trzeciego bloku leczenia konsolidującego (haM). W przypadku opóźnienia procedury przeszczepienia, należy podjąć leczenie podtrzymujące remisję stosowane w programie AML-BFM 2004 INTERIM.

Obecnie u dzieci z HR-AML w CR1 nie przeprowadza się auto-HSCT.

AML z niekorzytną odpowiedzią $\mathrm{w}$ 42. dobie leczenia

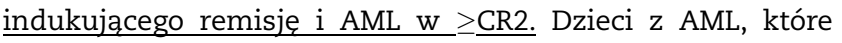
$\mathrm{w}$ 42. dobie leczenia indukującego nie osiągnęły CR1 (>5\% blastów w 14 dobie od rozpoczęcia bloku HAM) (poor

Tabela V - Wskazania do allogenicznej transplantacji komórek krwiotwórczych u dzieci i mlodzieży z HR-AML w CR1 i rekomendowany typ dawcy allogenicznych komórek krwiotwórczych wedlug programu AML-BFM 2012

Table V - Indications for allogeneic hematopoietic cell transplantation in children and adolescents with HR-AML in CR1 and recommended type of donor allogeneic hematopoietic cell according to the AML-BFM 2012 program

\begin{tabular}{|c|c|c|c|}
\hline \multicolumn{2}{|c|}{ WSKAZANIE DO ALLOGENICZNEJ HSCT } & \multirow{2}{*}{$\frac{\text { MSD }^{*}}{+}$} & \multirow{2}{*}{$\frac{\mathrm{MD}^{*}}{+}$} \\
\hline Aberracje genetyczne & FLT3-ITD + WT1mut & & \\
\hline & $12 \mathrm{p} / \mathrm{t}(2 ; 12)$ & + & + \\
\hline & Monosomia 7 bez rokowniczo korzystnych aberracji & + & + \\
\hline & $\mathrm{t}(4 ; 11)(\mathrm{q} 21 ; \mathrm{q} 23)$ & + & + \\
\hline & $\mathrm{t}(5 ; 11)(\mathrm{q} 35 ; \mathrm{p} 15.5)$ & + & + \\
\hline & $\mathrm{t}(6 ; 11)(\mathrm{q} 27 ; \mathrm{q} 23)$ & + & + \\
\hline & $\mathrm{t}(10 ; 11)(\mathrm{q} 22 ; \mathrm{q} 23)$ & + & + \\
\hline & $\mathrm{t}(6 ; 9)((\mathrm{p} 23 ; \mathrm{q} 24)$ & + & + \\
\hline & $\mathrm{t}(7 ; 12)(\mathrm{q} 36 ; \mathrm{p} 13)$ & + & + \\
\hline & $\mathrm{t}(9 ; 22)(\mathrm{q} 34 ; \mathrm{q} 11)$ & + & + \\
\hline & $\begin{array}{l}\text { Złożony kariotyp ( }>3 \text { aberracje; jedna zmiana strukturalna, bez } \\
\text { prognostycznie korzystnych aberracji; bez rearanżacji MLL) }\end{array}$ & + & + \\
\hline
\end{tabular}


Tabela VI - Wskazania do allogenicznej transplantacji komórek krwiotwórczych u dzieci i mlodzieży z HR-AML w CR1

i rekomendowany typ dawcy allogenicznych komórek krwiotwórczych wedlug programu AML-BFM 2004 INTERIM

Table VI - Indications for allogeneic hematopoietic cell transplantation in children and adolescents with HR-AML in CR1 and recommended type of donor allogeneic hematopoietic cells by AML-BFM 2004 INTERIM program

\begin{tabular}{|c|c|c|c|}
\hline WSKAZANIE DO ALLOGENICZNEJ HSCT & & MSD & $\mathrm{MD}^{* *}$ \\
\hline \multirow[t]{6}{*}{ Cytomorfologia blastów wg klasyfikacji FAB } & M0 & + & - \\
\hline & M1/M2 bez pałek Auera & + & - \\
\hline & M4 bez eozynofilii & + & - \\
\hline & M5 & + & - \\
\hline & M6 & + & - \\
\hline & M7 & + & - \\
\hline Niekorzystna odpowiedź na leczenie indukujące I linii & $>5 \% \mathrm{w} 15$. dobie & + & - \\
\hline Aberracje genetyczne & FLT3-ITD & + & - \\
\hline
\end{tabular}

responding AML; pr-AML) oraz dzieci z pierwszą wznową AML są obecnie leczone w ośrodkach PPGdsLBiCh według programu terapeutycznego (wersja z 5.11.2011 r.) [10] opracowanego na podstawie protokołu Relapsed-AML BFM 2001/ 02, a kwalifikacji do allo-HSCT lub auto-HSCT dokonuje się z uwzględnieniem przynależności do grupy ryzyka standardowego (wznowa $\geq 1$. roku od rozpoznania) lub wysokiego (niekorzystna odpowiedź w 42. dobie leczenia indukującego CR1 lub wznowa $<1$. roku od rozpoznania lub kolejna wznowa) oraz dostępności dawcy allogenicznych HSC na podstawie wytycznych zawartych $\mathrm{w}$ programie AML-SCT BFM-2007 [11] i Pediatric Relapsed AML 2010/01 [12] (Tab. VII). Podstawowym warunkiem kwalifikacji do HSCT jest uzyskanie pełnej remisji. Wyjątkiem od tej reguły są dzieci ze szpikiem aplastycznym bez cech regeneracji przez co najmniej 4 tygodnie po drugim bloku leczenia indukującego remisję (HAM), które nie osiągnęły CR1 przed rozpoczęciem tego bloku.

U pacjentów, którzy uzyskali pełną remisję, transplantację należy przeprowadzić nie później niż po upływie 4-6 tygodni od rozpoczęcia drugiego bloku leczenia reindukującego.
U dzieci z AML, u których wznowa wystąpiła $\geq 12$ miesięcy od rozpoznania (grupa ryzyka standardowego, SR), program zaleca allo-HSCT od MSD lub MD i dopuszcza auto-HSCT (jeśli brak jest MSD i MD), natomiast u dzieci z prAML oraz u tych, u których wznowę AML rozpoznano przed upływem 12 miesięcy od rozpoznania lub stwierdzono kolejną wznowę AML, dawcą komórek krwiotwórczych może być, w odpowiedniej kolejności, nie tylko MSD lub MD, ale także MMD i dopuszcza się auto-HSCT, jeśli brak jest jakiegokolwiek dawcy allogenicznych HSC. Po auto-HSCT stosuje się leczenie podtrzymujące.

Ostra białaczka promielocytarna (acute promyelocytic leukemia; APL). Według European LeukemiaNet (2009 r.) [13], allo-HSCT może być rekomendowana u tych pacjentów ze wznową APL, u których pomimo zastosowania kwasu transretinowego (all-trans retinoic acid; ATRA) z lub bez trójtlenku arsenu $\left(\mathrm{As}_{2} \mathrm{O}_{3}\right.$, Trisenox) nie uzyskano drugiej remisji molekularnej, oraz u tych chorych, u których czas trwania CR1 był krótki.

Ostra białaczka szpikowa u dzieci z zespołem Downa (DS-AML). U dzieci z DS-AML w CR1 allo-HSCT nie jest rekomendowana, ponieważ wyniki leczenia z zastosowaniem

Tabela VII - Wskazania do allogenicznej transplantacji komórek krwiotwórczych u dzieci i mlodzieży z AML z niekorzystną odpowiedzią w 42. dobie leczenia indukującego GR1 lub z pierwszą albo kolejną wznową AML według programów

terapeutycznych AML-SCT BFM-2007 i Pediatric Relapsed AML 2010/01

Table VII - Indications for allogeneic hematopoietic cell transplantation in children and adolescents with AML with unfavorable response in 42nd day of induction therapy CR1 or the first or subsequent relapse of AML according to therapeutic programs AMLSCT BFM-2007 and Pediatric Relapsed AML 2010/01

\begin{tabular}{|c|c|c|c|c|}
\hline & MSD & ${ }^{* *} \mathrm{MD}$ & MMD & AUTO \\
\hline $\begin{array}{l}\text { GRUPA RYZYKA STANDARDOWEGO } \\
\text { (późna wznowa, tj. wznowa } \geq 1 \text {. } \\
\text { roku od rozpoznania) }\end{array}$ & + & + & - & + (jeśli brak MSD i MD) \\
\hline $\begin{array}{l}\text { GRUPA RYZYKA WYSOKIEGO } \\
\text { (niekorzystna odpowiedź w } 42 . \\
\text { dobie leczenia indukującego CR1; } \\
\text { wczesna wznowa, tj. wznowa }<1 \text {. } \\
\text { roku od rozpoznania, kolejna wznowa) }\end{array}$ & + & + & + & + (jeśli brak MSD, MD i MMD) \\
\hline
\end{tabular}


chemioterapii o zredukowanej intensywności są bardzo dobre, a ryzyko wystąpienia zagrażającej życiu toksyczności narządowej kondycjonowania jest szczególnie wysokie [14].

AML jako drugi nowotwór. Rokowanie u dzieci z AML będącą drugim nowotworem jest na ogół niekorzystne. Stąd program Registry AML-BFM 2012 [9] zaleca po przeprowadzeniu w tej grupie dzieci dwóch bloków leczenia indukującego (AIE + HAM) i uzyskaniu pełnej remisji lub remisji z częściową odbudową szpiku, wykonanie allo-HSCT od najlepszego dostępnego dawcy allogenicznych HSC (MSD, MD lub MMD).

\section{Ostra białaczka wywodząca się z nieokreślonej linii komórkowej}

Zgodnie z ostatnią wersją klasyfikacji chorób rozrostowych układu krwiotwórczego oraz układu limfocytarnego wprowadzoną przez WHO w 2008 r. [15] do ostrych białaczek wywodzących się z nieokreślonej linii komórkowej zaliczana jest ostra białaczka niezróżnicowana (acute undifferentiated leukaemia; AUL) oraz ostra białaczka o mieszanym immunofenotypie (mixed phenotype acute leukemia; MPAL).

Ostra białaczka niezróżnicowana (acute undifferentiated leukaemia; AUL).Według rekomendacji programu Registry AML-BFM 2012 [9] dzieci z AUL powinny być leczone jak dzieci z AML z uwzględnieniem wskazań do HSCT aktualnie obowiązujących w tej grupie pacjentów.

Ostra białaczka o mieszanym immunofenotypie (mixed phenotype acute leukemia; MPAL). Na podstawie doświadczeń własnych PPGdsLBiCh [16], danych literaturowych [17] oraz zgodnie z programem Registry AML-BFM 2012 [9] allo-HSCT rekomendowana jest $u$ tych dzieci $z$ MPAL, u których rokowanie jest szczególnie niekorzystne, tj. u dzieci z BCR/ $A B L(+), u$ dzieci z rearanżacją $M L L(+)$, u niemowląt, u dzieci $\mathrm{z}$ niekorzystną odpowiedzią na leczenie indukujące remisję (wg kryteriów stosowanych u dzieci z ALL lub AML), u dzieci z białaczką dwuliniową oraz u dzieci, u których w trakcie leczenia stwierdzono zmianę fenotypu białaczki (tzw. lineage switch).

Przewlekła białaczka szpikowa (chronic myeloid leukemia; CML) Od 2008 r. dzieci z CML leczone są w Polsce zgodnie z programem CML PEAD II [18]. Niezależnie od fazy CML, w której doszło do rozpoznania białaczki, leczenie zawsze rozpoczyna się od zastosowania imatynibu w dawce zależnej od fazy choroby [18-20]. Wyjątek stanowią chorzy z mutacją T315I w obrębie domeny BCR-ABL, u których stwierdza się pierwotną oporność na działanie imatynibu, a także na inhibitory kinazy tyrozynowej nowej generacji, takie jak dazatynib i nilotynib. Jeśli odpowiedź molekularna jest dobra (redukcja ilości transkryptu do poziomu $<10$ kopii), to leczenie imatynibem należy kontynuować bez limitu czasowego. U dzieci z CML rozpoznaną w pierwszej fazie przewlekłej (chronic phase; CP) i leczonych imatynibem allo-HSCT należy przeprowadzić tylko w przypadku, gdy 1) stwierdza się niekorzystną odpowiedź na leczenie ocenianą za pomocą RQ-PCR dla genu BCR-ABL w punktach czasowych określonych programem terapeutycznym, 2) dojdzie do utraty korzystnej odpowiedzi molekularnej (wzrost liczby kopii transkryptu do poziomu > 10), 3) wystąpią istotne objawy uboczne związane $\mathrm{z}$ leczeniem imatynibem lub 4) współpraca z pacjentem i jego rodziną w zakresie systematycznego przyjmowania leku jest niedostateczna. U dzieci $\mathrm{z}$ de novo fazą zaostrzenia (accelerated phase; AP) lub de novo kryzą blastyczną (blastic crisis; BC) bez mutacji T315I podejmowana jest próba leczenia wysokimi dawkami imatynibu. W przypadku dobrej odpowiedzi na leczenie imatynibem należy jak najszybciej przeprowadzić allo-HSCT (szczegółowe kryteria oceny odpowiedzi na leczenie imatynibem określa program CML PEAD II). Natomiast jeśli odpowiedź jest niekorzystna, to najpierw stosuje się - w zależności od immunofenotypu blastów - leczenie indukujące jak dla ALL lub AML i w możliwie jak najkrótszym czasie po jego zakończeniu wykonywana jest allo-HSCT.

U chorych z CML i mutacją T315I, u których białaczkę rozpoznano w pierwszej $\mathrm{CP}$, transplantację należy wykonać wkrótce po ustaleniu rozpoznania, zanim wystąpi faza zaostrzenia (AP) lub kryza blastyczna (BC). Natomiast $\mathrm{u}$ chorych $\mathrm{z}$ ww. mutacją, u których rozpoznanie postawiono w fazie zaostrzenia lub w kryzie blastycznej, postępowanie jest takie samo jak $\mathrm{u}$ chorych $\mathrm{z}$ de novo AP lub BC bez ww. mutacji, którzy nie odpowiedzieli na leczenie imatynibem, tj. stosuje się - w zależności od immunofenotypu blastów - leczenie indukujące jak dla ALL lub AML i możliwie w najkrótszym czasie po jego zakończeniu należy przeprowadzić allo-HSCT.

U dzieci z CML dawcą allogenicznych HSC może być w wymienionej kolejności - nie tylko rodzeństwo zgodne w zakresie antygenów układu HLA (MSD), ale także zgodny (MD) (10/10 lub 9/10) lub częściowo niezgodny (MMD) dawca niespokrewniony lub dawca rodzinny.

Od 2009 r. SCT I-BFM Study Group rekomenduje u dzieci z CML nowy protokół CML-SCT-I-BFM (v. 4) [21], zgodnie z którym allo-HSCT poprzedzona jest kondycjonowaniem o zredukowanej intensywności (reduced intensity conditioning; RIC). Poszukiwanie dawcy należy wdrożyć u wszystkich pacjentów po uzyskaniu remisji hematologicznej za pomocą imatynibu. Dawcy HSC rekomendowani prze ten protokół, to MSD i MD (10/10 lub 9/10) oraz niespokrewniona krew pępowinowa (CB) zgodna w loci A, B i DRB1 (6/6) na poziomie allelicznym. Kiedy odpowiedni dawca zostanie zidentyfikowany, to transplantację należy wykonać, jeżeli stwierdza się:

- >10 kopii po 18 miesiącach leczenia imatynibem

- $>2$ kopii po 36 miesiącach leczenia imatynibem.

Jeżeli utracono uprzednio uzyskaną odpowiedź molekularną, wskazane jest podjęcie próby leczenia dazatynibem (jako chemioterapia niestandardową).

Zespół mielodysplastyczny (myelodysplastic syndrome; MDS) Zgodnie z przyjętą w 2003 r. klasyfikacją, obecnie u dzieci wyróżnia się trzy formy MDS, tj. 1) dziecięca cytopenię oporną na leczenie (RCC), 2) niedokrwistość oporną na leczenie z nadmiarem blastów (RAEB) oraz 3) niedokrwistość oporną na leczenie $\mathrm{z}$ nadmiarem blastów $\mathrm{w}$ fazie transformacji (RAEB-t) [22].

Aktualnie European Working Group on MDS in Childhood (EWOG-MDS) w rekomendacjach z dnia 28 sierpnia $2013 \mathrm{r}$. [23] zaleca wykonanie allo-HSCT u dzieci z niżej wymienionymi formami MDS wysokiego ryzyka:

1) RC z monosomią/delecją długiego ramienia chromosomu 7 lub ze złożonym kariotypem ( $\geq 2$ aberracje) i/lub 


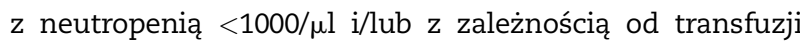
koncentratu erytrocytarnego i/lub płytek krwi;

2) RAEB;

3) RAEB-t;

4) MDR-AML (AML evolving from MDS).

Ponadto zaleca się zastosowanie allo-HSCT u dzieci, u których stwierdzono MDS jako drugi nowotwór po wcześniej stosowanym leczeniu onkologicznym (therapy-related MDS; t-MDS) oraz u dzieci z MDS, który rozwinął się po leczeniu immunoablacyjnym ciężkiej nabytej niedokrwistości aplastycznej (SAA).

We wszystkich wyżej wymienionych wskazaniach allo-HSCT należy wykonać jak najszybciej po ustaleniu rozpoznania, bez jakiejkolwiek uprzedniej chemioterapii, za wyjątkiem MDR-AML, w której dopuszcza się na zasadzie indywidualnej zastosowanie chemioterapii cytoredukcyjnej. Dawcą allogenicznych HSC dla dzieci z MDS może być - w odpowiedniej kolejności - zarówno rodzeństwo zgodne w zakresie antygenów układu HLA (MSD), jak i zgodny (MD) (10/10 lub 9/10) lub częściowo niezgodny dawca niespokrewniony lub rodzinny (MMD).

\section{Młodzieńcza białaczka mielomonocytarna (juvenile myelo- monocytic keukemia; JMML)}

JMML wraz z przewlekłą białaczką mielomonocytową (CMML) i przewlekłą białaczką szpikową bez t(9; 22) (Ph-ujemna CML) zaliczana jest obecnie do zespołów o mieszanym mieloproliferacyjno-mielodysplastycznym charakterze [24].

Przed kwalifikacją do allo-HSCT u wszystkich pacjentów z objawami JMML należy wykonać w wymazach ze śluzówki policzka badania genetyczne w kierunku mutacji germinalnych PTPN11 lub CBL, ponieważ na ich podłożu mogą rozwinąć się przejściowe zespoły mieloproliferacyjne przypominające JMML, nie wymagające pilnej allo-HSCT, które mogą dobrze odpowiedzieć na leczenie cytoredukujące prowadzone za pomocą 6-merkaptopuryny (6-MP) [23].

Natomiast $\mathrm{u}$ chorych $\mathrm{z}$ JMML ze stwierdzonymi somatycznymi mutacjami K-RAS, N-RAS i PTPN-11 lub z chorobą Recklinghausena typu 1 konieczna jest jak najszybsza allo-HSCT. U pacjentów z wysoką leukocytozą i zaburzeniami funkcji płuc i/lub znaczną hepatomegalią i/lub splenomegalią przed allo-HSCT wskazane może być leczenie cytoredukujące z użyciem 6-MP i arabinozydu cytozyny [23].

Dawcą allogenicznych HSC dla dziecka z JMML może być - w odpowiedniej kolejności - MSD, MD lub MMD.

\section{Chłoniaki nieziarnicze (non-Hodgkin's lymphoma; NHL)} NHL wywodzace się z linii limfocytów B (B-NHL). Pacjenci z B-NHL są obecnie leczeni według przyjętych od kwietnia 2013 r. protokołów Inter-B-NHL-Ritux [25] i Inter-B-NHL-low risk [26], a w przypadku niepowodzenia leczenia są każdorazowo konsultowani przez krajowego koordynatora i indywidualnie podejmowana jest decyzja o zastosowaniu megachemioterapii i auto- lub allo-HSCT. U pacjentów z PMLBCL (primary mediastinal large B-cell lymphoma) zabieg auto-HSCT rozważa się w przypadku obecności żywych komórek w usuniętym guzie resztkowym. Uzależnione jest to jednak od rodzaju resekcji.

NHL wywodzące się $\mathrm{z}$ prekursorów limfocytów $\mathrm{T}$ lub B (pre-T NHL i pre-B NHL). W aktualnie stosowanym programie leczenia dla chłoniaków wywodzących się $\mathrm{z}$ prekursorów limfocytów $\mathrm{T}$ lub $\mathrm{B}$ (EURO-LB, oparty na BFM-90) [27] nie określono kryteriów kwalifikacji chorych do przeprowadzania transplantacji allogenicznych lub autologicznych HSCT. Wyniki badań, w większości o charakterze retrospektywnym, świadczą o wysokiej lekooporności u chorych $\mathrm{z}$ progresją $\mathrm{w}$ trakcie chemioterapii I linii oraz w przypadku wczesnych nawrotów do 12 miesięcy od diagnozy. Ta grupa chorych może odnieść korzyści z megachemioterapii z następczym allo-HSCT. Stosowanie autotransplantacji może być uzasadnione w nawrotach izolowanych (za wyjątkiem OUN) występujących ponad 12 miesięcy od rozpoznania. W przypadku wystąpienia nawrotu chłoniaka limfoblastycznego $\mathrm{z}$ linii T lub B kwalifikacji do allo-HSCT lub auto-HSCT dokonuje się w zależności od stopnia ryzyka niepowodzenia, typu dostępnego dawcy allogenicznych HSC i po konsultacji z krajowym koordynatorem leczenia tej grupy chłoniaków u dzieci.

Anaplastyczny chłoniak wielkokomórkowy (anaplastic large cell llymphoma; ALCL). Z uwagi na niezadowalające wyniki leczenia, u dzieci $\mathrm{z}$ nawrotami ALCL odstąpiono od metody autologicznej transplantacji komórek krwiotwórczych. Poniższe zestawienie prezentuje aktualne wskazania (protokół ALCL-Relapse 2012) [28] do allo-HSCT u dzieci z ALCL:

1. progresja ALCL CD3(+) lub CD3(-) w trakcie terapii I linii wg protokołu ALCL99 $(\rightarrow$ terapia II linii wg ALCL-Relapse 2012 + allo-HSCT od MSD, MD lub MMD);

2. wznowa ALCL CD3(+) po zakończeniu terapii I linii wg ALCL99 ( $\rightarrow$ terapia II linii wg ALCL-Relapse $2012+$ allo-HSCT od MSD lub MD);

NHL u dzieci i młodzieży z zespołem Nijmegen (Nijmegen breakage syndrome; NBS) i innymi zespołami zaburzeń naprawy DNA. U dzieci z NBS i innymi zespołami zaburzeń naprawy DNA, u których doszło do rozwoju NHL lub ALL i uzyskano CR1, wskazane jest wykonanie allo-HSCT, która powinna być przeprowadzona najprawdopodobniej najlepiej wkrótce po uzyskaniu remisji [29].

\section{Chłoniak Hodgkina (Hodgkin's lymphoma; HL)}

Zgodnie z obecnie obowiązującym protokołem EuroNet-PHL-C1 Europejskiej Sieci Grup Pediatrycznych ds. Chłoniaka Hodgkina [30], auto-HSCT jest rekomendowana wyłącznie $\mathrm{u}$ pacjentów $\mathrm{z}$ progresją HL oraz $\mathrm{u}$ pacjentów $\mathrm{z}$ grupy pośredniego i wysokiego ryzyka, ze wznową, w leczeniu której stwierdzono nieadekwatną odpowiedź ocenianą po dwóch cyklach chemioterapii (IEP i ABVD). Rola allo-HSCT w leczeniu HL nie została ostatecznie ustalona i obecnie dopuszcza się ją tylko u pacjentów ze wznową, u których nie udało się pozyskać komórek do autoprzeszczepu, $\mathrm{u}$ chorych ze wznową po auto-HSCT oraz u pacjentów z kolejną wznową HL.

\section{Zespoły histiocytarne u dzieci}

Histiocytoza komórek Langerhansa (Langerhans cell histiocytosis; LCH). Według wytycznych LCH Histiocyte Society Evaluation and Treatment Guidelines z 2009 r. [31], allo-HSCT poprzedzoną kondycjonowaniem o zredukowanej intensywności (RIC) należy przeprowadzić u pacjentów z wielonarządową LCH, którzy nie odpowiedzieli na 6-tygodniowe standardowe 
leczenie indukujące I linii (prednizon + vinblastyna) oraz na dwa bloki leczenia II linii (kladrybina + cytarabina). Jak wynika $\mathrm{z}$ dotychczasowych danych $\mathrm{z}$ piśmiennictwa, allo-HSCT może poprawić rokowanie także u tych chorych z LCH, u których doszło do wczesnej wznowy choroby.

Limfohistiocytoza hemofagocytarna (hemophagocytic lymphohistiocytosis; HLH). Leczenie zarówno pierwotnej (rodzinnej, genetycznie uwarunkowanej), jak i wtórnej (nabytej) HLH prowadzone jest obecnie zgodnie z programem terapeutycznym HLH-2004 rekomendowanym przez Histiocyte Society [32]. Allo-HSCT jest metodą leczenia z wyboru pierwotnej $\mathrm{HLH}$, a transplantację poprzedzoną RIC należy przeprowadzić natychmiast po zidentyfikowaniu odpowiedniego dawcy, najlepiej od zgodnego w HLA dawcy rodzinnego lub niespokrewnionego (MD), jednak w razie potrzeby można przeprowadzić transplantację od częściowo niezgodnego dawcy niespokrewnionego lub rodzinnego (MMD), w tym od dawcy haploidentycznego. Ze względu na ryzyko nosicielstwa HLH transplantacja od rodzeństwa nie jest rekomendowana. Po ustaleniu rozpoznania należy natychmiast nie tylko wszcząć poszukiwanie dawcy allogenicznych HSC, ale także leczenie według wyżej wymienionego programu z użyciem deksametazonu, etopozydu, cyklosporyny A oraz dokanałowych podań metotreksatu i prednizolonu, tak aby jeśli to możliwe przed allo-HSCT osiągnąć - na ogół po 8 tygodniach terapii - status choroby nieaktywnej (non-active disease): bez gorączki, bez splenomegalii, bez cytopenii (Hb $>9 \mathrm{~g} / \mathrm{dL}$, płytki $\geq 100 \times 10^{9} / \mathrm{L}$, ANC $\geq 0,5 \times 10^{9} / \mathrm{L}$ ), bez hipertrójglicerydemii ( $<265 \mathrm{mg} / \mathrm{dL})$, bez hiperferrytynemii $(\leq 500 \mu \mathrm{g} / \mathrm{L})$, bez zmian w płynie mózgowo-rdzeniowym oraz zmniejszenie stężenia rozpuszczalnego receptora IL-2 (sCD25) w surowicy krwi - jeśli badanie jest dostępne.

Podobne zasady postepowania obowiązują u chorych z HLH wtórną lub niezweryfikowaną w badaniach genetycznych, u których stwierdza się oporność na leczenie według ww. programu lub wznowę HLH po tego zakończeniu leczenia.

Wskazania do HSCT $w$ nowotworowych guzach litych u dzieci

\section{Zwojak zarodkowy (neuroblastoma; NBL)}

Auto-HSCT u dzieci z HR-NBL (dzieci $\leq 1$. rż.: stopnie zaawansowania 2., 3., 4. i $4 \mathrm{~s}$ z amplifikacją onkogenu N-MYC; dzieci >1. rż.: stopień zaawansowania 4. oraz stopnie: 2. i 3. z amplifikacją onkogenu N-MYC), które obecnie leczone są według programu HR-NBL-1/SIOPEN 2002 [33], przeprowadza się nie później niż w 210. dniu od rozpoczęcia leczenia indukcyjnego (po zakończeniu chemioterapii indukcyjnej \pm 2-4 cykli TVD, po zabezpieczeniu odpowiedniej dawki autologicznych HSC i próbie całkowitego chirurgicznego usunięcia guza pierwotnego) oraz u dzieci, u których wystąpiła wznowa NBL z przerzutami i/lub amplifikacją N-MYC, a wcześniej nie przeprowadzono auto-HSCT. Ponadto u dzieci $z$ progresją lub ze wznową NBL, która wystąpiła pomimo wcześniej przeprowadzonej auto-HSCT, opcją kliniczną stosowaną w niektórych ośrodkach, ale nie będącą standardem, jest haploidentyczna HSCT z następczą immunoterapią, pod warunkiem że przy użyciu chemioterapii II linii uzyskano dobrą odpowiedź na leczenie.

\section{Mięsak Ewinga (Ewing's sarcoma; ES)}

Dzieci z ES leczone są obecnie według programu EWING-2008 [34] i kwalifikowane do auto-HSCT poprzedzonej:

- megachemioterapią konsolidującą z użyciem busulfanu i melfalanu (BuMel), jeśli: 1) u pacjenta ze zlokalizowaną chorobą po zakończeniu chemioterapii indukcyjnej stwierdza się wykładniki niekorzystnej odpowiedzi na leczenie ( $\geq 10 \%$ żywych komórek w utkaniu resekowanego guza i/lub objętość resekowanego guza $\geq 200 \mathrm{ml}$ ) i/lub 2) w chwili rozpoznania stwierdza się przerzuty do płuc (grupa R2);

- megachemioterapią konsolidującą z treosulfanem i melfalanem (TreoMel), jeśli stwierdza się pierwotnie rozsiany nowotwór (grupa R3).

Pacjenci ze wznową mięsaka Ewinga, którzy byli w grupie R1 (bez megachemioterapii) po osiągnięciu CR2, są kandydatami do auto-HSCT poprzedzonej megachemioterapią BuMel lub TreoMel. Natomiast pacjenci ze wznową po auto-HSCT lub wznową oporną na leczenie ze względu na niekorzystne rokowanie są kandydatami do terapii eksperymentalnych, w tym do allo-HSCT.

\section{Wskazania do HSCT w nierozrostowych chorobach u dzieci i młodzieży}

We wrodzonych i nabytych nierozrostowych chorobach układu krwiotwórczego wykonuje się wyłącznie allo-HSCT, której celem jest odtworzenie w pełni sprawnego układu krwiotwórczego u chorych niewydolnością krwiotworzenia i/lub wymiana układu krwiotwórczego biorcy obciążonego defektem genetycznym i stąd funkcjonalnie niesprawnego.

\section{Niewydolność układu krwiotwórczego}

\section{Nabyta niewydolność układu krwiotwórczego}

Ciężka nabyta niedokrwistość aplastyczna (severe acquired aplastic anemia; SAA). Leczenie dzieci z SAA, z uwzględnieniem allo-HSCT, prowadzone jest obecnie zgodnie $z$ zamieszczonymi poniżej wytycznymi zawartymi w programie EWOG-SAA 2010 (wersja z dn. 24.04.2012 r.) [35]:

1) jeżeli wśród rodzeństwa zidentyfikowano dawcę w pełni zgodnego w HLA (MSD), to metodą leczenia $\mathrm{z}$ wyboru jest MSD-HSCT, którą należy przeprowadzić jak najszybciej od rozpoznania,

2) jeżeli MSD jest niedostępny, należy niezwłocznie podjąć leczenie immunoablacyjne z użyciem końskiej globuliny antytymocytarnej (ATGAM ${ }^{\circledR}$ Pfizer) lub króliczej (Thymoglobulin ${ }^{\circledR}$ Genzyme), w przypadku niedostępności pierwszego z wymienionych preparatów oraz wszcząć poszukiwanie dawcy niespokrewnionego,

3) jeżeli do 120. dnia po leczeniu immunoablacyjnym nie uzyskano zadowalającej odpowiedzi na to leczenie, a zidentyfikowany został zgodny dawca niespokrewniony (MD), należy wykonać MD-HSCT.

Jednak wobec istotnie gorszych wyników leczenia immunoablacyjnego z zastosowaniem króliczej globuliny antytymocytarnej w porównaniu z wynikami tego leczenia prowadzonego za pomocą globuliny pochodzenia końskiego, której dostępność jest od kilku lat znacznie ograniczona [36], a także w związku ze znaczną poprawą wyników MD-HSCT, 
które obecnie nie różnią się istotnie od wyników MSD-HSCT [37-40], PPGdsTKK stoi na stanowisku, że w przypadku braku MSD i niedostępności końskiej globuliny antytymocytarnej, przy jednoczesnej szybkiej dostępności dawcy niespokrewnionego zgodnego w HLA na poziomie alleli (10/10) (MD) jako leczenie I linii należy przeprowadzić MD-HSCT.

Nocna napadowa hemoglobinuria (paroxysmal nocturnal hemoglobinuria; $\mathrm{PNH}$ )

Badanie na obecność klonu PNH metodą cytofluorymetrii przepływowej (brak w erytrocytach ekspresji CD55 [DAF] i CD59 [MIRL]) należy wykonać u każdego dziecka z rozpoznaniem aplazji szpiku, mielodysplazji, zakrzepicy i niedokrwistości hemolitycznej z ujemnymi odczynami Coombsa. W populacji pediatrycznej PNH występuje rzadko i może mieć inny przebieg niż u osób starszych, ponieważ mniejsza jest częstość hemoglobinurii, natomiast częściej występują pancytopenia lub dysplazja. Ocenia się, że klon PNH może występować u $20 \%$ chorych z niedokrwistością aplastyczną lub MDS.

U pacjentów z PNH z objawami kryz hemolitycznych jako leczenie pierwszej linii rekomendowany jest obecnie inhibitor komplementu (eculizumab), który jak dotąd nie jest dostępny w Polsce. Ponadto allo-HSCT jest nadal jedyną metodą terapeutyczną umożliwiającą wyleczenie PNH poprzez eliminację patologicznego klonu.

Stąd allo-HSCT należy przeprowadzić nie tylko u każdego chorego z wykładnikami niewydolności szpiku i/lub mielodysplazji i/lub nawracającymi zagrażającemu życiu powikłaniami zakrzepowymi, ale także u pacjentów z powtarzającymi się kryzami hemolitycznymi [41]. Optymalnym dawcą allogenicznych HSC dla dziecka $\mathrm{z}$ PNH jest rodzeństwo zgodne w zakresie antygenów układu HLA (MSD), a przy braku zgodnego dawcy wśród rodzeństwa należy rozważyć wykonanie allo-HSCT od zgodnego dawcy niespokrewnionego lub rodzinnego (MD).

\section{Zespoły wrodzonej niewydolności szpiku kostnego}

Poniżej zostały zestawione wskazania i przeciwskazania do allo-HSCT u dzieci z zespołami wrodzonej niewydolności szpiku przyjęte przez PPGdsTKK na podstawie rekomendacji EBMT [42] oraz najnowszych dostępnych publikacji podsumowujących dotychczasowe postępy allo-HSCT u dzieci z tymi zespołami $[43,44]$. W przygotowaniu znajdują się rekomendacje grupy ekspertów EBMT Pediatric Diseases Working Party.

U wszystkich dzieci z którymkolwiek z zespołów wrodzonej niewydolności szpiku allo-HSCT należy przeprowadzić bezpośrednio po stwierdzeniu choćby jednego z uznanych wskazań do zabiegu i dokonaniu doboru odpowiedniego dawcy allogenicznych komórek krwiotwórczych!

Wrodzona niedokrwistość aplastyczna typu Fanconiego (Fanconi anemia; FA)

1. Wskazania do allo-HSCT:

- obecność aberracji genetycznej szczególnie predysponującej do wystąpienia ewolucji klonalnej w kierunku MDS lub AML (-7 lub -3q lub bialleliczna mutacja genu BRCA);

- cytopenia ( $\mathrm{Hb}<8 \mathrm{~g} / \mathrm{dL}$, ANC $<0,5 \times 10^{9} / \mathrm{L}$ i/lub liczba płytek krwi $<20 \times 10^{9} / \mathrm{L}$ ) i związana z tym zależność od przetoczeń koncentratu krwinek czerwonych i koncentratu płytek krwi

- ewolucja klonalna w kierunku MDS lub AML;
2. Dodatkowe zalecenia co do czasu wykonania allo-HSCT:

- zanim liczba ogółem przetoczeń koncentratu krwinek czerwonych przekroczy $20 \mathrm{i} / \mathrm{lub}$ zanim po pierwszym przetoczeniu koncentratu płytek krwi zajdzie potrzeba kolejnych przetoczeń płytek krwi;

- zanim wystąpi ewolucja klonalna w kierunku MDS lub AML;

- przed ukończeniem 10. rż.

3. Przeciwskazania do allo-HSCT:

- mozaicyzm bez klonalnej ewolucji.

Wrodzona niedokrwistość hipoplastyczna BlackfanaDiamonda (Blackfan-Diamond anemia; B-DA)

1. Wskazania do allo-HSCT:

a. ustalone:

- oporność na kortykosteroidoterapię (dwukrotnie stwierdzony brak wzrostu liczby retikulocytów po zastosowaniu kortykosteroidów)

- ewolucja klonalna w kierunku MDS lub AML,

b. rozważane:

- zależność od kortykosteroidoterapii, tj. odpowiedź na leczenie dopiero przy dawce prednizonu powyżej $0,3 \mathrm{mg} / \mathrm{kg} /$ dzień

- zależność od transfuzji erytrocytów.

2. Przeciwskazania:

- ze względu na brak dostatecznej liczby danych dotyczących wyników allo-HSCT od dawców alternatywnych, tj. od dawców innych niż rodzeństwo zgodne w HLA, jak dotąd tych zabiegów u dzieci z B-DA nie rekomenduje się. Ciężka wrodzona neutropenia (severe congenital neutrope$\underline{\text { nia; SCN) }}$

Wskazania do allo-HSCT:

a. ustalone:

- oporność na ludzki rekombinowany czynnik wzrostu kolonii granulocytarnych (G-CSF) (>20 $\mu \mathrm{g} / \mathrm{kg} / \mathrm{dzień}$ w ciągu 6 miesięcy);

- ewolucja klonalna w kierunku MDS lub AML;

- mutacja GATA2;

b. rozważane:

- zależność od przewlekle stosowanych wysokich dawek G-CSF (co najmniej $10 \mu \mathrm{g} / \mathrm{kg} /$ dzień przez co najmniej 3 miesiące w roku), zwłaszcza jeśli spostrzegane są nawracające zakażenia bakteryjne i wśród rodzeństwa jest dawca zgody w HLA.

Wrodzona amegakariocytoza (congenital amegakariocytic thrombocytopienia; CAMT)

Wskazania do allo-HSCT:

- pancytopenia (płytki krwi $<20 \times 10^{9} / \mathrm{L}$, ANC $<0,5 \times 10^{9} / \mathrm{L}$, $\mathrm{Hb}<8 \mathrm{~g} / \mathrm{dL})$;

- ewolucja klonalna w kierunku MDS lub AML.

Zespół Shwachman i Diamonda (Shwachman-Diamond syndrome; SDS)

Wskazania do allo-HSCT:

- cytopenia (ANC $<0,5 \times 10^{9} / \mathrm{L}, \mathrm{Hb}<9 \mathrm{~g} / \mathrm{dL}$ i płytki krwi $<100 \times 10^{9} / \mathrm{L}$ ) stwierdzona przed 3. miesiącem życia;

- ewolucja klonalna w kierunku MDS lub AML.

Wrodzona dyskeratoza (dyskeratosis congenita; DC)

1. Wskazania do allo-HSCT:

- cytopenia (ANC $<0,5 \times 10^{9} / \mathrm{L}$, płytki krwi $<20 \times 10^{9} / \mathrm{L}$, $\mathrm{Hb}<8 \mathrm{~g} / \mathrm{dL})$;

- ewolucja klonalna w kierunku MDS lub AML. 


\section{Przeciwskazania:}

- marskość płuc i/lub wątroby i/lub zaburzenia funkcji tych narządów.

\section{Wrodzone niedobory odporności}

Wskazania co do allo-HSCT, dobór optymalnego dawcy HSC oraz rekomendacje dotyczące procedury transplantacyjnej $\mathrm{u}$ dzieci $\mathrm{z}$ wrodzonymi niedoborami odporności zostały zebrane oraz szczegółowo opisane w EBMT/ESID Guidelines for Haematopoietic Stem Cell Transplantation for Primary Immunodeficiences z 2011 r. Dokument jest dostępny na stronie internetowej EBMT (www.ebmt.org) [45].

\section{Choroby metaboliczne}

Spośród chorób metabolicznych, w których zalecana jest allo-HSCT, należy przede wszystkim wymienić adrenoleukodystrofię sprzężoną z chromosomem X w fazie asymptomatycznej (wskaźnik Loesa <8), mukopolisacharydozę typu I przed ukończeniem 2. rż. (zespół Hurlera za wyjątkiem odmian Scheie i Hurler/Scheie), a także alfa-mannozydozę, leukodystrofię metachromatyczną (postać młodzieńcza) oraz osteopetrozę (za wyjątkiem postaci neurodegeneracyjnej) [46].

\section{Wkład autorów/Authors' contributions}

Według kolejności.

\section{Konflikt interesu/Conflict of interest}

Nie występuje.

\section{Finansowanie/Financial support}

Nie występuje.

\section{Etyka/Ethics}

Treści przedstawione $\mathrm{w}$ artykule są zgodne $\mathrm{z}$ zasadami Deklaracji Helsińskiej, dyrektywami EU oraz ujednoliconymi wymaganiami dla czasopism biomedycznych.

\section{P I ŚM I E N N I C T W O/R E FERENCES}

[1] Gratwohl A, Baldomero H, Sureda A. Indications for and current practice of allogeneic and autologous HSCT. W: Apperley J, Carreras E, Gluckman E, Masszi T, reds. Haematopoietic stem cell transplantation. EBMT-ESH, Paryż: The EBMT Handbook; 2012. p. 303-315.

[2] ALL IC-BFM 2009 - final version of the therapy protocol from August 14, 2009.

[3] AIEOP-BFM ALL 2009 - international collaborative treatment protocol for children and adolescents with acute lymphoblastic leukemia - last version August 2013.
[4] EsPhALL - an open-label study to evaluate the supply and efficacy of IMATINIB with chemotherapy in pediatric patients with $\mathrm{Ph}+/ \mathrm{BCR}-\mathrm{ABL}$ acute lymphoblastic leukemia $(\mathrm{Ph}+\mathrm{ALL})$ - version 01.12.2009.

[5] INTERFANT-06 - international collaborative treatment protocol for infants under one year with acute lymphoblastic or biphenotypic leukemia - version 14 . Amendment 4.0: May 23, 2012.

[6] IntReALL 2010 - high risk group - international study for treatment of childhood relapsed ALL 2010. Protocol version 1.2, Date: 23.02.2011.

[7] IntReALL SR 2010 - international study for treatment of standard risk childhood relapsed ALL 2010. Protocol version 1.7, Date: 01.07.2012.

[8] Protokół leczenia ostrej białaczki mieloblastycznej u dzieci i młodzieży. Opracowany na podstawie programu AML-BFM 2004 INTERIM. Do stosowania w ośrodkach PPGdsLBiCh, Kraków 2005.

[9] Registry AML-BFM 2012. English version - no. 1 from 01.07.2012.

[10] Protokół leczenia ostrej białaczki szpikowej opornej na leczenia oraz wznowy białaczki szpikowej u dzieci i młodzieży. Opracowany na podstawie protokołu RELAPSED AML 2001/01 International Berlin-Frankfurt-Münster Study Group. Do stosowania w ośrodkach PPGdsLBiCh. Wersja z dnia 5 listopada $2011 \mathrm{r}$.

[11] AML SCT-BFM 2007 - allogeneic stem cell transplantation for children, adolescents and young adults with relapsed or refractory AML. Version 5.0 from 05.03.2010.

[12] Pediatric Relapsed AML 2010/01 - clinical study protocol on the treatment of children and adolescents with refractory or relapsed acute myeloblastic leukemia. Version 5.0 from 16.04.2013.

[13] Sanz MA, Grimwade MS, Lowenberg B, et al. Management of acute promyelocytic leukemia: recommendations from an expert panel on behalf of the European LeukemiaNet. Blood 2009;1113:1875-1891.

[14] Hiztler JK, Wensheng H, Cairo M, et al. Outcome of transplantation for acute myelogenous leukemia in children with Down syndrome. Biol Blood Marrow Transplant 2013;19:893-897.

[15] Borowitz MJ, Béné M-C, Harris NL, Porwit A, Matutes E. Acute leukemias of ambiguous lineage. W: Swerdlow SH, Campo E, Harris NL, Jaffe ES, Pileri SA, Stein H, Thiele J, Vardiman JW, reds. WHO Classification of Tumours of Haematopoietic and Lymphoid Tissues. Lyon: International Agency for Research on Cancer; 2008. p. 149-156.

[16] Konatkowska B, Wachowiak J, Derwich K, et al. Retrospektywna ocena wyników leczenia dzieci z ostra białaczką bifenotypową i ostrą białaczką z koekspresją determinant $\mathrm{z}$ linii limfoidalnej i mieloidalnej $\mathrm{w}$ latach 1995-2005 w materiale PPGdsLBiCh. Acta Haematol Pol 2005;36(supl.2):161-162.

[17] Gerr H, Zimmermann M, Schrappe M, et al. Acute leukemias of ambiguous lineage in children: characterization, prognosis and therapy recommendations. Br J Haematol 2010;149(1):84-92.

[18] CML-paed-II - protocol for standarized diagnostic procedures, registration, and treatment recommendations in children and adolescents with Philadelphia chromosome-positive chronić myeloid leukemia (CML). Version: November 2006.

[19] Suttorp M, Millot F. Treatment of pediatric chronić myeloid leukemia in the year 2010: use of tyrosine kinase inhibitors and stem cell transplantation. Hematology Am Soc Hematol Educ Program 2010;368-376.

[20] Suttorp M, Eckardt L, Tauer JT, Millot F. Managemet of chronic leukemia in childhood. Curr Hematol Malig Rep 2012;7:116-124. 
[21] CML-SCT-IBFM - protocol on allogeneic stem cell transplantation in paediatric CML. Version 4.0 from 12.12.2008.

[22] Niemeyer CM, Baumann I. Classification of childhood aplastic leukemia and myelodysplastic syndrome. Hematology AM Soc Hematol Educ Program 2011;84-89.

[23] EWOG MDS guidelines for hematopoietic stem cell transplantation (HSCT) in childhood MDS and JMML. Version 1.2 from 01.09.2013.

[24] Baumann I, Bennett JM, Niemeyer CM, Thiele J, Shannon K. Juvenile myelomonocytic leukemia. W: Swerdlow SH, Campo E, Harris NL, Jaffe ES, Pileri SA, Stein H, Thiele J, Vardiman JW, reds. WHO Classification of Tumours of Haematopoietic and Lymphoid Tissues. Lyon: International Agency for Research on Cancer; 2008. p. 82-84.

[25] EICNHL-COG Inter-B-NHL ritux 2010 - Intergroup trial for children or adolescents with B-cell NHL or B-ALL. Version 1.0 from 16th December 2010.

[26] Inter B-NHL 2010 low/intermediate - LMB based therapeutic recommendations for low/intermediate risk B-cell NHL in children and adolescents. Version 1.0 from April 2011.

[27] Euro-LB 02 Treatment Protocol for T-cell and B-precursor cell lymphoblastic lymphoma of the European Intergroup Co-operative on Childhood Non-Hodgkin-Lymphoma (EICNHL) from 08.2004.

[28] ALCL-Relapse 2012 - EICNHL treatment protocol for relapsed anaplastic large cell lymphoma of childhood and adolescence. Version 2.0 Last modification 17.09.2012.

[29] Albert MH, Gennery AR, Greil J, et al. Successful SCT for Nijmegen breakage syndrome. Bone Marrow Transplant 2010;45:622-626.

[30] EuroNet-PHL-C1 - first international study of Pediatric Hodgkin's Lymphoma Group for classical Hodgkin's lymphoma in children and adolescents. Final version of 07.08.2006, last amendment no. 6 dated 12.11.2012.

[31] Langerhans Cell Histiocytosis - Histiocyte Society Evaluation and Treatment Guidelines. April 2009.

[32] HLH-2004 - treatment protocol of the Second International HLH Study. January 2004.

[33] HR-NBL-1/SIOPEN - high risk neuroblastoma study 1 of SIOP-Europe. Amended version valid per 01.07.2009.

[34] EWING 2008 - joint protocol of European and North America Ewing sarcoma study groups. Version 1.5 of 20.04.2009.

[35] EWOG-SAA 2010 - amended version of 24.04.2012.
[36] Marsh JC, Bacigalupo A, Schrezenmeier H, et al. Prospective study of rabbit antithymocyte globulin and cyclosporine for aplastic anemia from the EBMT Severe Aplastic Anaemia Working Party. Blood 2011;119(2):5391-5396.

[37] Kennedy-Nasser AA, Leung KS, Mahajan A, et al. Comparable outcomes of matched-related and alternative donor stem cell cell transplantation for pediatric severe aplastic anemia. Biol Blood Marrow Transplant 2006;12:1277-1284.

[38] Samarasinghe S, Steward C, Hiwarkar P, et al. Excellent outcome of matched unrelated donor transplantationin paediatric aplastic anaemia following failure with immunosupressive therapy: a United Kingdom multicentre retrospective experience. Brit J Haematol 2012;157:339-346.

[39] Szpecht D, Gorczyńska E, Kałwak K, et al. Matched sibling versus matched unrelated donor allogeneic hematopoietic stem cell transplantation in children with severe acquired aplastic anemia: an experience of the Polish Pediatric Group for Hematopietic Stem Cell Transplantation. Arch Immunol Ther Exp (Warsz) 2012;60:225-233.

[40] Maury S, Balére-Appert M-L, Pollichieni S, et al. Outcome of patients activating an unrelated donor search for severe aplastic anemia. Am J Hematol 2013;88:868-873.

[41] Curran KJ, Kernan NA, Prockop SE, et al. Paroxysmal nocturnal hemoglobinuria in pediatric patients. Pediatr Blood Cancer 2012;59:525-529.

[42] Gluckman E. Hereditary bone marrow failure syndromes. W: Apperley J, Carreras E, Gluckman E, Masszi T, reds. Haematopoietic Stem Cell Transplantation - the EBMT Handbook. Paris: Wyd. 6. ESH-EBMT; 2012. p. 572-583.

[43] Myers KC, Davies SM. Hematopoietic stem cell transplantation for bone marrow failure syndromes in children. Biol Blood Marrow Transplant 2009;15:279-292.

[44] Mehta P, Locatelli F, Stary J, Smith FO. Bone marrow transplantation for inherited bone marrow failure syndromes. Pediatr Clin North Am 2010;57:147-170.

[45] EBMT/ESID Guidelines for Haematopoietic Stem Cell Transplantation for Primary Immunodeficiences z $2011 \mathrm{r}$. Dokument jest dostępny na stronie internetowej EBMT (www.ebmt.org).

[46] Boelens JJ, Bierings M, Wynn R. HSCT in inborn errors of metabolism and osteopetrosis. W: Apperley J, Carreras E, Gluckman E, Masszi T, reds. Haematopoietic stem cel transplantation - the EBMT Handbook. Paris: Wyd. 6. ESHEBMT; 2012. p. 558-571. 